\title{
EFFECT OF SOME CLEANING PRODUCTS ON BLOOD DNA RETRIEVAL FROM CLOTH
}

\author{
Hayam Z. Thabet ${ }^{1}$, Nagwa M. Ghandour ${ }^{1 *}$, Ragaa H. Salama ${ }^{2}$ \\ Department of Forensic Medicine and Clinical Toxicology ${ }^{1}$, Department of Medical \\ Biochemistry $^{2}$ Faculty of Medicine - Assiut University, Egypt
}

*Corresponding author: N. Ghandour, n_ghandour10@yahoo.com

\begin{abstract}
The ability to extract DNA and PCR amplification from biological stains is a key element in forensic genetics. Attempts to remove blood stains using different types of cleaning methods represent a routinely faced forensic problem. Objective: This work was done to evaluate the effect of some cleaning products on the quantity and quality of extracted DNA from bloodstained cloth. Methods: Blood samples were applied to cotton and silk cloth. After drying, the cloth was subjected to the effect of some cleaning products \{Clorox (bleach), Dettol (disinfectant), Persil (detergent), Vanish (stain remover) and distilled water . DNA extraction and PCR amplification were done to estimate the quantity and quality of extracted DNA by spectrophotometer and gel electrophoresis. Results: There was significant reduction in amount of extracted DNA from silk compared to cotton cloth in all samples including controls. Detectable amounts of DNA could be recovered after amplification by PCR with all types of cleaning agents. Cleaning with Vanish resulted in most significant decrease in recovered DNA amount, while cleaning with Clorox resulted in highest recovery of DNA in both cotton and silk cloth. Gel electrophoresis showed that Clorox, Persil and distilled water had no effect on quality of extracted DNA compared to control samples in cotton cloth, while Vanish and Dettol had the most degraded effect. In silk cloth the quality of DNA was affected in all samples mostly with Vanish and Persil. Conclusion: DNA could be recovered from cloth after exposure to different types of cleaning products.
\end{abstract}

Key words: Bloodstains, Cleaning products, DNA.

\section{INTRODUCTION}

Blood, as a physical clue found in many violence cases, has the capacity to provide valuable intelligent evidence for forensic purposes and crime reconstruction (Passi et al., 2012).

The retrieval of DNA from blood stained cloth provides evidence that can link a criminal or the victim with the scene of crime (Peschel et al., 2011).

DNA techniques are the most advanced tools for human identification. During the past years, a great number of methods for DNA extraction and typing had been introduced into forensic science, with considerable success (van
Oorshot et al., 2010).

In forensic molecular genetic analysis, the use of new, sensitive PCRMultiplex-Kits are suitable for low copy number DNA and lead to valuable DNA profiles even in invisible samples (Castelló et al., 2010), or in cases that seemed to be hopeless a few years ago (Kamphausen et al.,2015).

Sometimes, criminals try to avoid leaving evidence at the crime scene by washing away bloodstains by a variety of cleaning agents, but fortunately they leave traces on the surfaces, which may be invisible to the naked eye (Castelló et al., 2009). A wide variety of cleaning 
chemicals may be used, they may cause potential contamination of the biological material with subsequent DNA content degradation, so, makes the production of a conclusive evidence difficult (Creamer et al., 2005 and Harris et al., 2006).

The present work was conducted to evaluate the effect of some cleaning products on the quantity and quality of extracted DNA from bloodstained cloth.

\section{MATERIAL \& METHODS}

This work was conducted in the Central Laboratories of Faculty of Agriculture \& Molecular biology Research Unit. Assiut University. Egypt.

\section{Materials}

- Fabric supports for bloodstains (cotton and silk).

- Products for cleaning (from the market) :

1- Clorox (commercial household chlorine bleach).

2- Dettol (Disinfectant).

3- Vanish (Stain remover).

4- Persil powder (Detergent).

- Distilled water.

- Deionized water.

Methods

i. Sample collection and preparation:

Cotton and silk fabrics were sourced from a local fabric store. Each fabric was cut into squares $(2 \times 2 \mathrm{~cm}$ for each) on lab counter using gloves and autoclaved scissors. Five hundred $\mu \mathrm{L}$ of venous blood from the same donor, not subjected to any form of anticoagulant, was added to each piece of cloth, allowed to dry for 48 hours at room temperature, and then kept in dry paper envelope (de Almeida et al., 2011 and Passi et al., 2012).

ii. Treatment of samples with cleaning products:

Blood-stained pieces of cotton cloth were grouped from 1 to $7(1:+$ ve control samples, 2: -ve unstained control samples, 3: Clorox treated samples, 4: Dettol treated samples, 5: Vanish treated samples, 6: Persil treated samples and 7: Distilled Water treated samples). Blood-stained pieces of silk cloth were grouped from 8 to $14(8:+$ ve control samples, 9: -ve unstained control samples, 10: Clorox treated samples, 11: Dettol treated samples, 12: Vanish treated samples, 13: Persil treated samples and 14: Distilled Water treated samples). Each group was presented by 3 samples. The composition and source of cleaning products were listed in Table (1).

Each sample was put in a separate bottle containing $5 \mathrm{ml}$ of the tested cleaning agents prepared according to manufacturer's instructions. The sample was shaken by (BLBBY Orbital shaker, Stuart scientific, made in UK) for 150 Revolutions/min (rpm) for $10 \mathrm{~min}$. Then left to dry at room temperature without any protection as described by Harris et al. (2006). 
Table (1): List for composition and source of cleaning products used.

\begin{tabular}{|c|c|c|}
\hline Cleaning agents & Concentration & Manufacture \\
\hline Clorox ${ }^{\circledR}($ Bleach) & $\begin{array}{l}<5 \% \text { sodium } \\
\text { hypochlorite } \\
(\mathrm{NaOCl})\end{array}$ & $\begin{array}{l}\text { Egyptian Company for household products. } \\
\text { Under license of Clorox® Oakland, } \\
\text { California. }\end{array}$ \\
\hline $\begin{array}{l}\text { Dettol® } \\
\text { (Disinfectant) }\end{array}$ & $\begin{array}{l}4.8 \% \quad \mathrm{~W} / \mathrm{V} \\
\text { Chloroxylenol }\end{array}$ & $\begin{array}{l}\text { Royal Cosmetics for Reckitt Benckiser } \\
\text { (Egypt ltd). Under license of Reckitt } \\
\text { Benckiser (Ireland Limited). }\end{array}$ \\
\hline Persil@ (Detergent) & Sodium borate. & $\begin{array}{l}\text { Henkel (Egypt ltd) Under license of Henkel } \\
\text { (Germany). }\end{array}$ \\
\hline $\begin{array}{l}\text { Vanish } \AA \quad \text { (Stain } \\
\text { remover) }\end{array}$ & $\begin{array}{l}\text { sodium } \\
\text { percarbonate }\end{array}$ & $\begin{array}{l}\text { Reckitt Benckiser Arabia. Made in Dubai. } \\
\text { Under license of Reckitt Benckiser (Poland } \\
\text { Limited). }\end{array}$ \\
\hline
\end{tabular}

\section{iii.DNA extraction:}

First, each cloth was soaked with $100 \mu \mathrm{l}$ of deionized water for a minimum of 1day. The substrate was then placed into a spin basket and centrifuged for 15 minutes to obtain the sample (Spear and Khoshkebari, 2001 and Choi et al., 2014).

Extraction was done using the Patho Gene-spin ${ }^{\mathrm{TM}}$ DNA/RNA Extraction Kit (iNtRON Biotechnology. Made in Korea).Lot. No. 11650150. Cat. No.17154 according to manufacturer's guidelines. First, by adding $300 \mu 1$ of the Lysis Buffer to $100 \mu 1$ of the sample, mixing by vortex for 15 seconds, incubate at room temperature overnight. Then $300 \mu 1$ of Binding Buffer, complete mix well by gentle vortex and place a spin column in a $2 \mathrm{ml}$ collection tube. Load lysates on the column and centrifuge at $13.000 \mathrm{rpm}$ for $1 \mathrm{~min}$. Discard solution in collection tube and place the column back in the same $2 \mathrm{ml}$ collection tube. Add 500 $\mu 1$ of Washing Buffer A to the column and centrifuge at $13.000 \mathrm{rpm}$ for $1 \mathrm{~min}$. Discard solution in collection tube and place the column back in the same $2 \mathrm{ml}$ collection tube. Add $500 \mu 1$ of Washing Buffer B to the column and centrifuge at $13.000 \mathrm{rpm}$ for $1 \mathrm{~min}$. Discard solution in collection tube and place the column back in the same $2 \mathrm{ml}$ collection tube. Centrifuge for $1 \mathrm{~min}$ at $13.000 \mathrm{rpm}$. Place the column in an RNase-free $1.5 \mathrm{ml}$ microcentrifuge tube and add $30 \mu 1$ of Elution Buffer directly on the spin column membrane. Lastly, incubate at room temperature for $1 \mathrm{~min}$ and centrifuge for $1 \mathrm{~min}$ at 13.000 rpm (Intronbio, 2015).

iv. Quantitation of extracted DNA:

After extraction, quantity of extracted DNA is estimated by spectrophotometry.

DNA concentration of each sample was measured by using the GeneQuant II Full-spectrum Spectrophotometer (GeneQuant 1300 - 80-2015-98, Serial No: 76923. Made in Sweden).

The concentration of DNA extracted was assessed at $260 \mathrm{~nm}$ and $280 \mathrm{~nm}$. The ratio between the reading at 260 and 280 $\mathrm{nm}$ (OD 260/280) provided an estimation of purity of DNA.

\section{v. Quality of extracted DNA:}

RAPD Analysis (Random Amplified Polymorphic DNA)

PCR amplification of random segments of genomic DNA with single primer of arbitrary nucleotide sequence is performed to check the intactness of the DNA (Shams et al., 2011).

The major advantage of RAPD includes that, it does not require any 
specific knowledge of the DNA sequence of the target gene. Great diagnostic power due to vast range of potential primers can be used. Reproducible RAPD bands can be found by careful selection of primers, optimization of PCR condition for target species and replication to ensure that only reproducible bands are scored.

(Kumari and Thakur, 2014).

PCR was carried out with a Fast Gene Kit for Real-Time PCR System using the manufacturer's recommendation (made in Germany). The total reaction volume was $25 \mu \mathrm{l}$. Each tube contained $2 \mu \mathrm{l}$ dNTPs Mix (2.5mM each), $2 \mu \mathrm{l}$ of primer (Opc-18 5'-TGAGTGGGTG-3'), $0.3 \mu 1$ Taq DNA polymerase $(5 \mathrm{U} / \mu \mathrm{l})$,2 $\mu \mathrm{l} \quad \mathrm{Mgcl}_{2}$ $(25 \mathrm{mM}), 1 \mu \mathrm{l}$ of DNA template $(50 \mathrm{ng})$ and $17 \mu \mathrm{l}$ amplification-grade water .The amplification was done using BIORAD Thermal Cycler C1000 (Serial no cc008315, Singapore).The cycling protocol was: an initial denaturation at $95^{\circ} \mathrm{C}$ for 4 min followed by 35 cycles of $94{ }^{\circ} \mathrm{C}$ for $30 \mathrm{~s}, 35^{\circ} \mathrm{C}$ for $45 \mathrm{~s}$, and $72^{\circ} \mathrm{C}$ for $60 \mathrm{~s}$, and a final extension at $72{ }^{\circ} \mathrm{C}$ for $10 \mathrm{~min}$. The PCR products were analyzed by electrophoresis on $1 \%$ Ethidium Bromide stained agarose gels in Trisborate- EDTA (TBE) buffer. Five microleter $(5 \mu \mathrm{l})$ of the sample was mixed with $2 \mu l$ gel loading dye and was loaded into the wells of submerged gel. The gel was allowed to run for half an hour at $80 \mathrm{~V}$, and was visualized and photographed with a (Bio-RAD) Gel documentation system (BIORAD, USA) with serial No 1708169 (Dissing et al., 2010 and Phillips et al., 2012).

Single, large, sharp, unified, clearly recognizable band indicated good quality of extracted DNA. While smear, short, sheared band indicated degraded poor quality, as described by Shams et al. (2011) and Passi et al. (2012).

\section{vi. Ethical considerations:}

This research was approved by The Research Ethics Committee of the Faculty of Medicine-Assiut University (Ref code: 17300077). It dealt only with author's blood sample.

\section{vii. Statistical analysis:}

The data collected were entered and analyzed using the Statistical Package for the Social Sciences (SPSS version 20.0) software. Chicago, USA. P value was set at $<0.05$ for significant results .

\section{RESULTS}

The macroscopic appearance of samples was demonstrated in Figure (1). Considerable amount of blood residues could still be noticed in cotton cloth samples, while the color was nearly faded in silk cloth samples.

\section{i. Quantitation of extracted DNA} amount by spectrophotometry:

The absorbance of DNA at 260 and $280 \mathrm{~nm}$ in different samples were measured. It ranged between 1.08 - 2 that indicated that the extracted DNA was free from protein contamination.

The Quantity of extracted DNA (ng/ $\mu \mathrm{l})$ from samples (cotton and silk) was expressed as Mean $\pm \mathrm{SE}$ as shown in Table (2).

Table (2) and Figure (2) show that there is highly significant decrease $(\mathrm{P} \leq$ 0.001 ) of amount of extracted DNA in cotton samples compared to silk samples in all groups including control.

The amount of extracted DNA from cotton samples is shown in Figure (3). It is observed that there is highly significant decrease $(\mathrm{P} \leq 0.001)$ in the amount of extracted DNA in all treated group samples compared to +ve control group. DNA amount is $(45.70 \mathrm{ng} / \mu \mathrm{l}$ $\pm 0.38)$ in + ve control group, $(39.17 \mathrm{ng} / \mu \mathrm{l}$ $\pm 0.15)$ in Clorox treated group, (29.90 $\mathrm{ng} / \mu \mathrm{l} \pm 0.21)$ in Dettol treated group, (19.83 $\mathrm{ng} / \mu \mathrm{l} \pm 0.27)$ in Vanish treated 
group, (34.20 $\mathrm{ng} / \mu \mathrm{l} \pm 0.53)$ in Persil treated group and $(32.83 \mathrm{ng} / \mu \mathrm{l} \pm 0.80)$ in Distilled Water treated group. Vanish is shown to have the highest cleaning effect, indicated by the decreased amount of extracted DNA from cotton cloth, while Clorox is the least effective one.

The amount of extracted DNA from silk samples is shown in Figure (4). It is observed that there is highly significant decrease $(P \leq 0.001)$ in the amount of extracted DNA in all treated group samples compared to +ve control group. DNA amount is $(27.57 \mathrm{ng} / \mu \mathrm{l} \pm 0.52)$ in +ve control group, $(19.90 \mathrm{ng} / \mu 1 \pm 0.06)$ in Clorox treated group, (18.80 $\mathrm{ng} / \mu \mathrm{l} \pm 0.44)$ in Dettol treated group, $(10.13 \mathrm{ng} / \mu \mathrm{l} \pm 0.19)$ in Vanish treated group, $(15.13 \mathrm{ng} / \mu \mathrm{l} \pm 0.24)$ in Persil treated group and $(14.60 \mathrm{ng} / \mu \mathrm{l} \pm 0.35)$ in Distilled Water treated group. Vanish also is shown to have the highest cleaning effect, indicated by the decreased amount of extracted DNA from silk cloth, while Clorox is the least effective one.
RAPD Analysis (Random Amplified Polymorphic DNA)

The quality of the isolated DNA used in PCR amplification reaction in agarose gel electrophoresis is demonstrated in Fig. (5) and (6). The size of PCR product of all the samples has been analyzed by making a comparison with 3000 bp marker ladder. Gel electrophoresis of blood samples extracted from cotton cloth, as shown in Fig. (5), reveals that in Clorox, Persil and Distilled water treated samples, no degradation are observed. Integrated DNA (large and clearly recognizable bands) is indicative of intact DNA. Comparatively, shearing of DNA has been observed with both Vanish and Dettol treated samples, which is indicative of degraded DNA.

Gel electrophoresis of silk cloth, as shown in Fig. (6), reveals ill-defined shearing of DNA bands in Clorox, Dettol and Distilled water treated samples. Poor yield of DNA have been observed in both Vanish and Persil treated samples.

\section{ii. Quality of extracted DNA:}

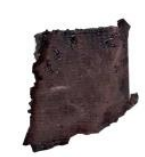

(1)

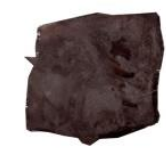

(8)

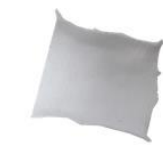

(2)

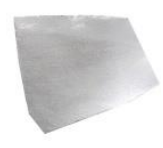

(9)

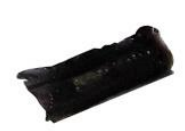

(3)

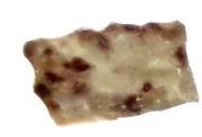

(10)

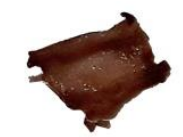

(4)

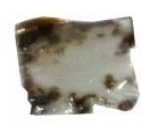

(11)

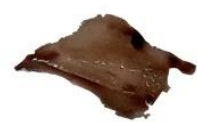

(5)

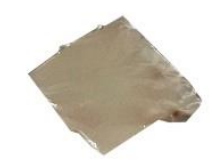

(12)

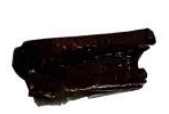

(6)

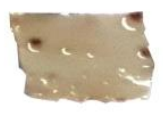

(13)

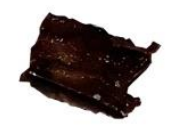

(7)

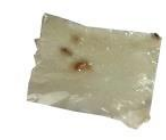

(14)

Figure (1) Macroscopic appearance of samples showing:

+ ve control (Blood stained) samples: sample (1) cotton cloth and sample (8) silk cloth. -ve control (unstained) samples: sample (2) cotton cloth and sample (9) silk cloth.

Clorox treated samples: sample (3) cotton cloth and sample (10) silk cloth.

Dettol treated samples: sample (4) cotton cloth and sample (11) silk cloth.

Vanish treated samples: sample (5) cotton cloth and sample (12) silk cloth.

Persil treated samples: sample (6) cotton cloth and sample (13) silk cloth.

Distilled Water treated samples: sample (7) cotton cloth and sample (14) silk cloth. 
Table (2): The Quantity of extracted DNA (ng/ $\mu \mathrm{l})$ from samples (cotton and silk)

\begin{tabular}{|c|c|c|c|c|c|c|}
\hline & \multicolumn{3}{|c|}{ Cotton cloth samples } & \multicolumn{3}{c|}{ Silk cloth samples } \\
\hline +ve control & 45.70 & \pm & 0.38 & $27.57 \quad * * *$ & \pm & 0.52 \\
\hline Clorox & 39.17 & \pm & $0.15 \quad \# \# \#$ & $* * * 19.90$ & \pm & $0.06 \# \# \#$ \\
\hline Dettol & 29.90 & \pm & $0.21 \# \# \#$ & $* * * 18.80$ & \pm & $0.44 \# \# \#$ \\
\hline Vanish & 19.83 & \pm & 0.27 \#\#\# & $* * * 10.13$ & \pm & 0.19 \#\#\# \\
\hline Persil & 34.20 & \pm & 0.53 \#\#\# & $* * * 15.13$ & \pm & $0.24 \# \# \#$ \\
\hline DW & 32.83 & \pm & $0.80 ~ \# \# \#$ & $* * * 14.60$ & \pm & 0.35 \#\#\# \\
\hline
\end{tabular}

Values are presented as mean (mean of 3 samples for each group) $\pm \mathrm{SE}$.

Significant compared cotton versus silk samples $* * *$ statistically significant difference $(\mathbf{p}<0.001)$ Significant compared to +ve control group \#\# statistically significant difference $(p<0.001)$
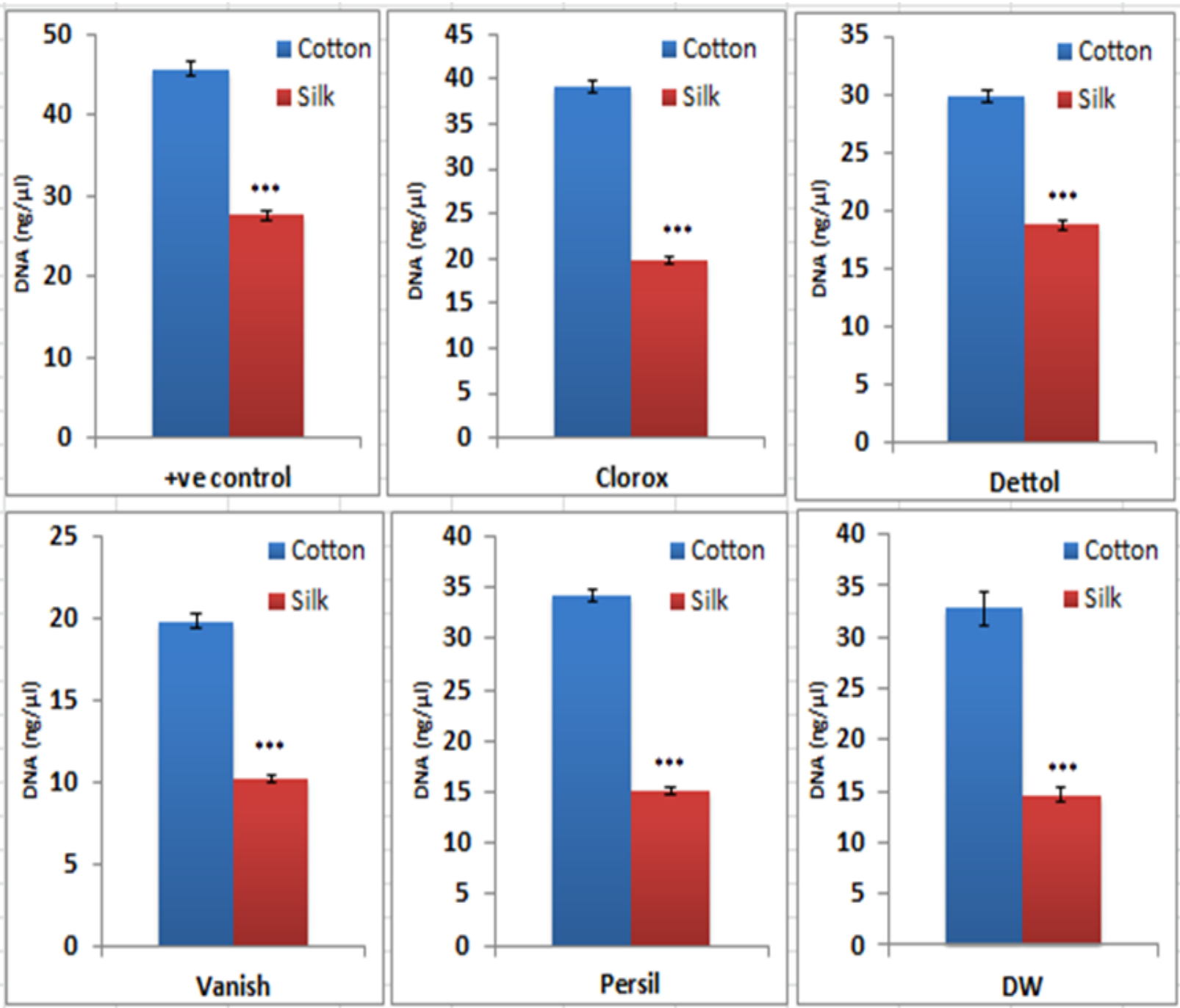

Figure (2) Comparison of DNA quantification (cotton versus silk) in all group samples.

$* * *$ Statistically significant difference $(\mathbf{p}<0.001)$ 


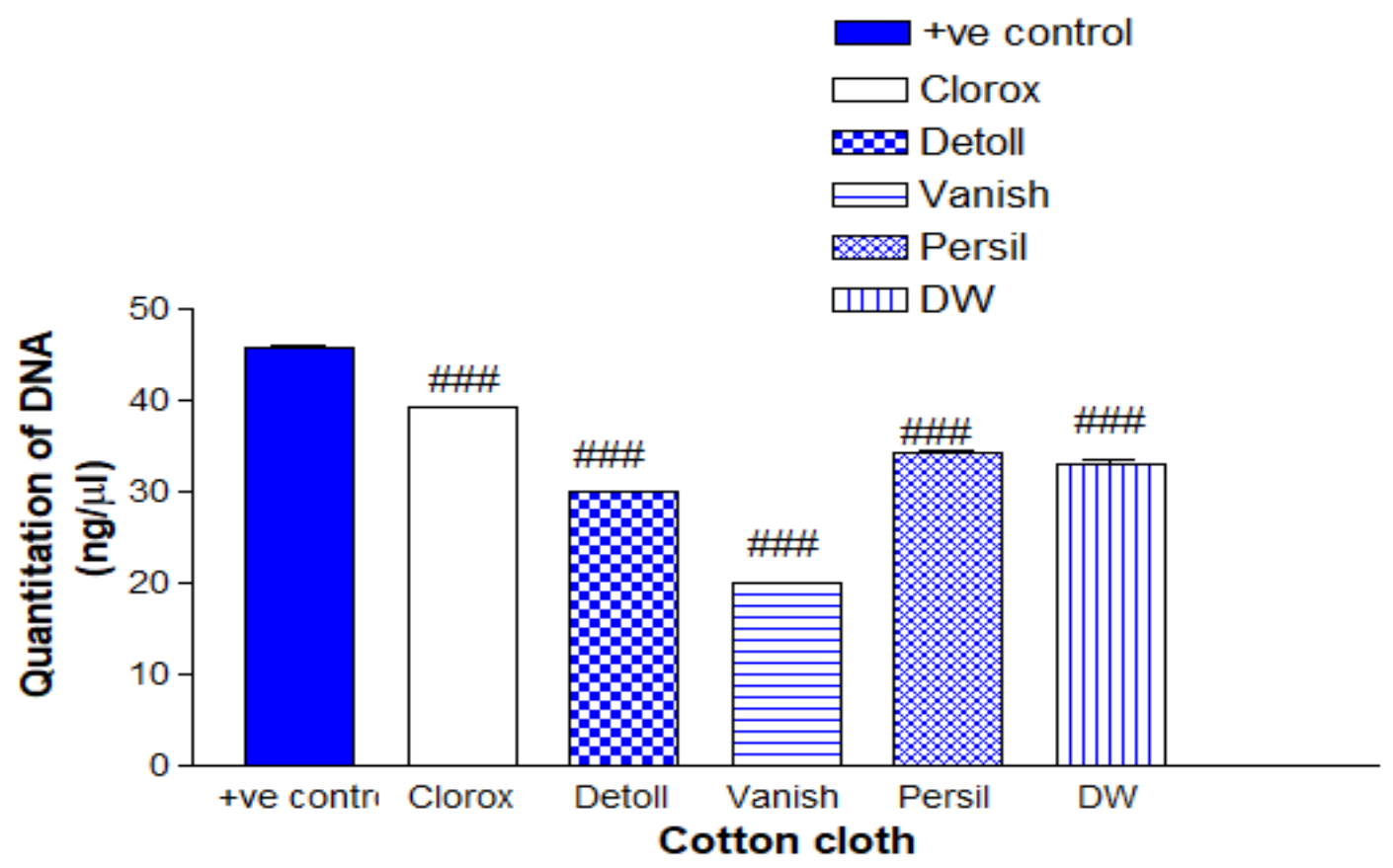

Figure (3): Comparison of DNA quantification in cotton cloth samples of all groups \#\#\# Statistically significant difference $(p<0.001)$ as compared to +ve control

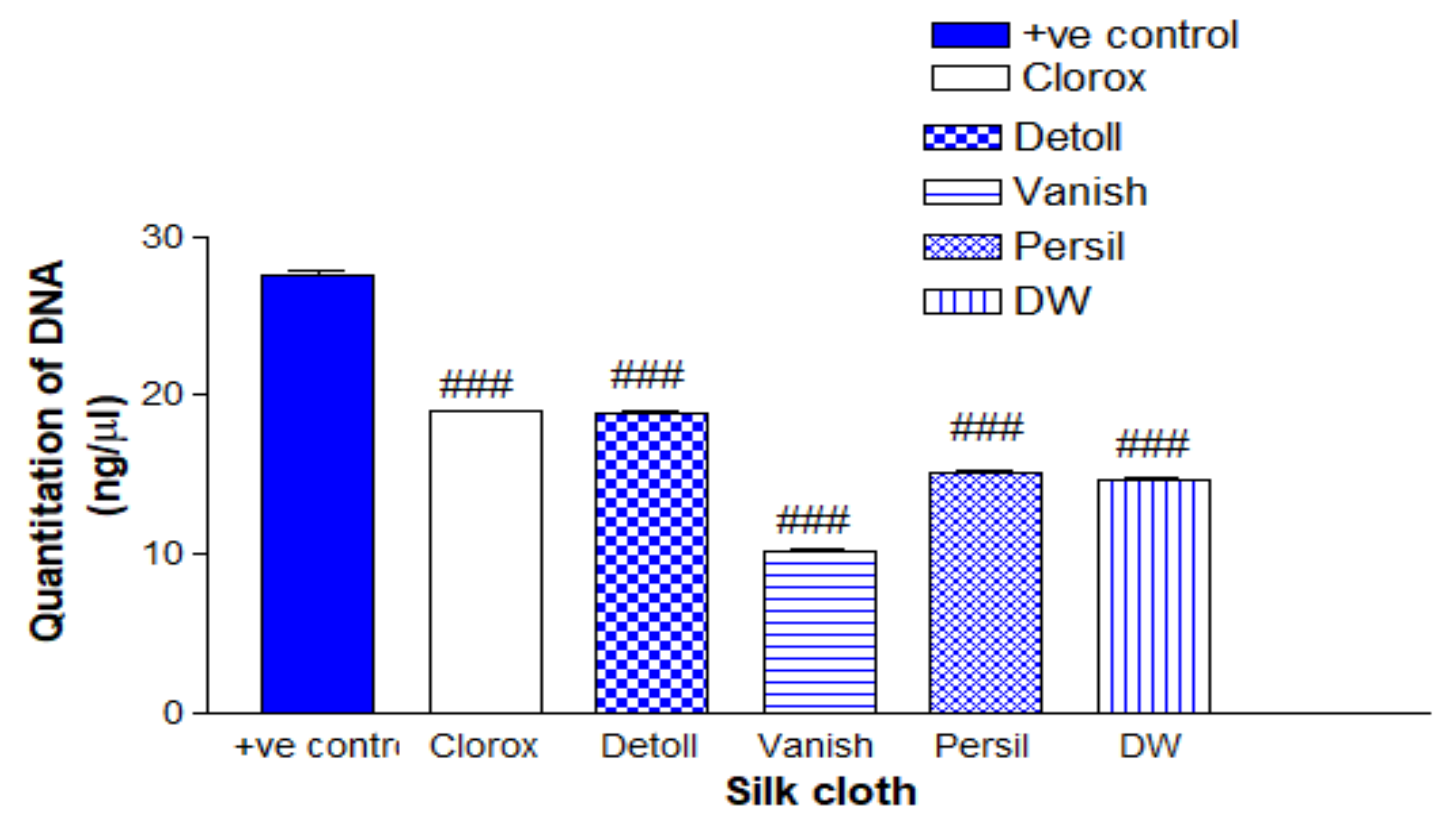

Fig (4) Comparison of DNA quantification in silk cloth samples of all groups \#\#\# Statistically significant difference $(p<0.001)$ as compared to +ve control 


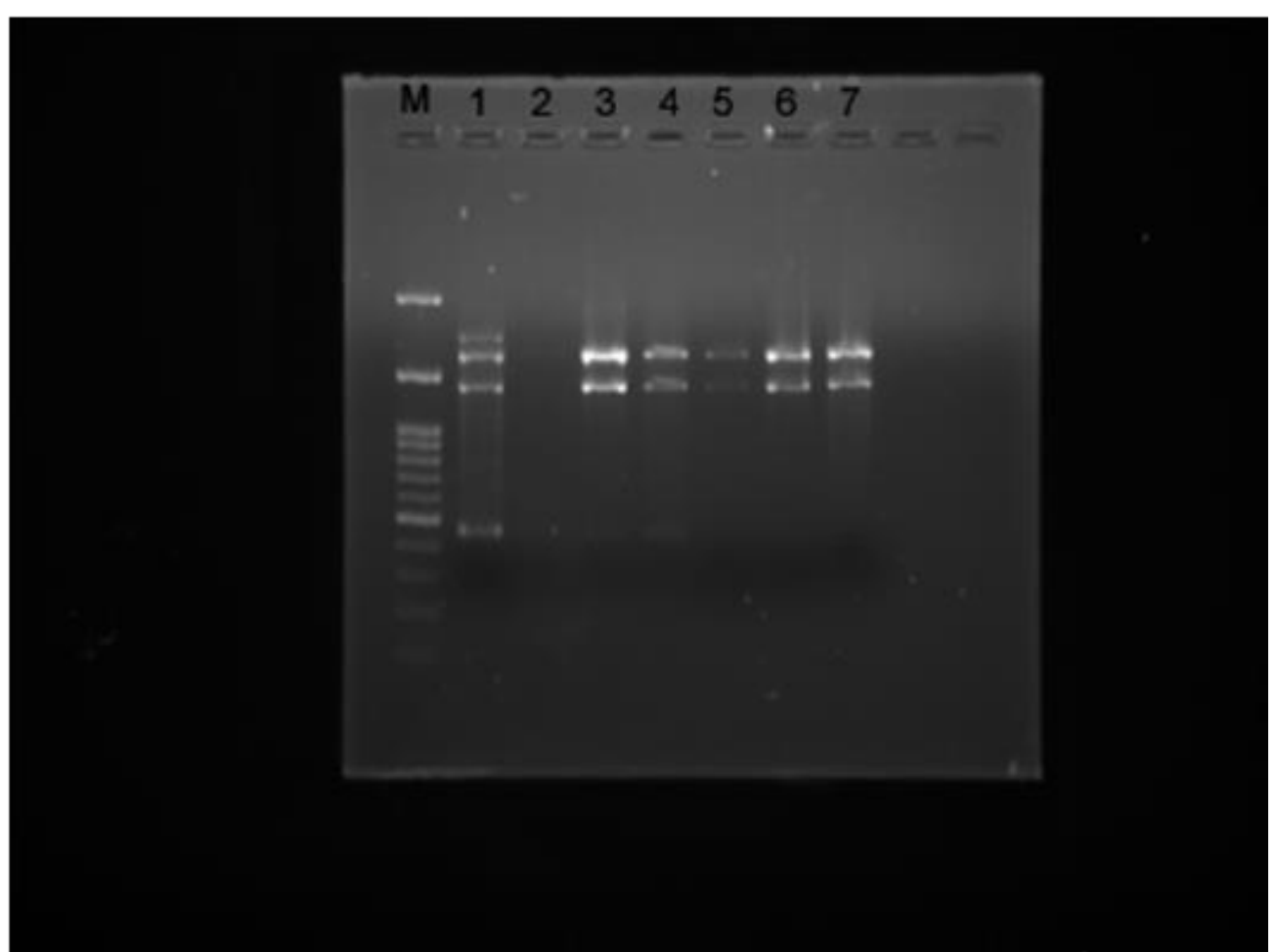

Figure (5): $1 \%$ agarose gel electrophoresis stained with Etidium bromide showing PCR product of amplification of cotton cloth samples of all groups (M=3000bp molecular weight ladder).

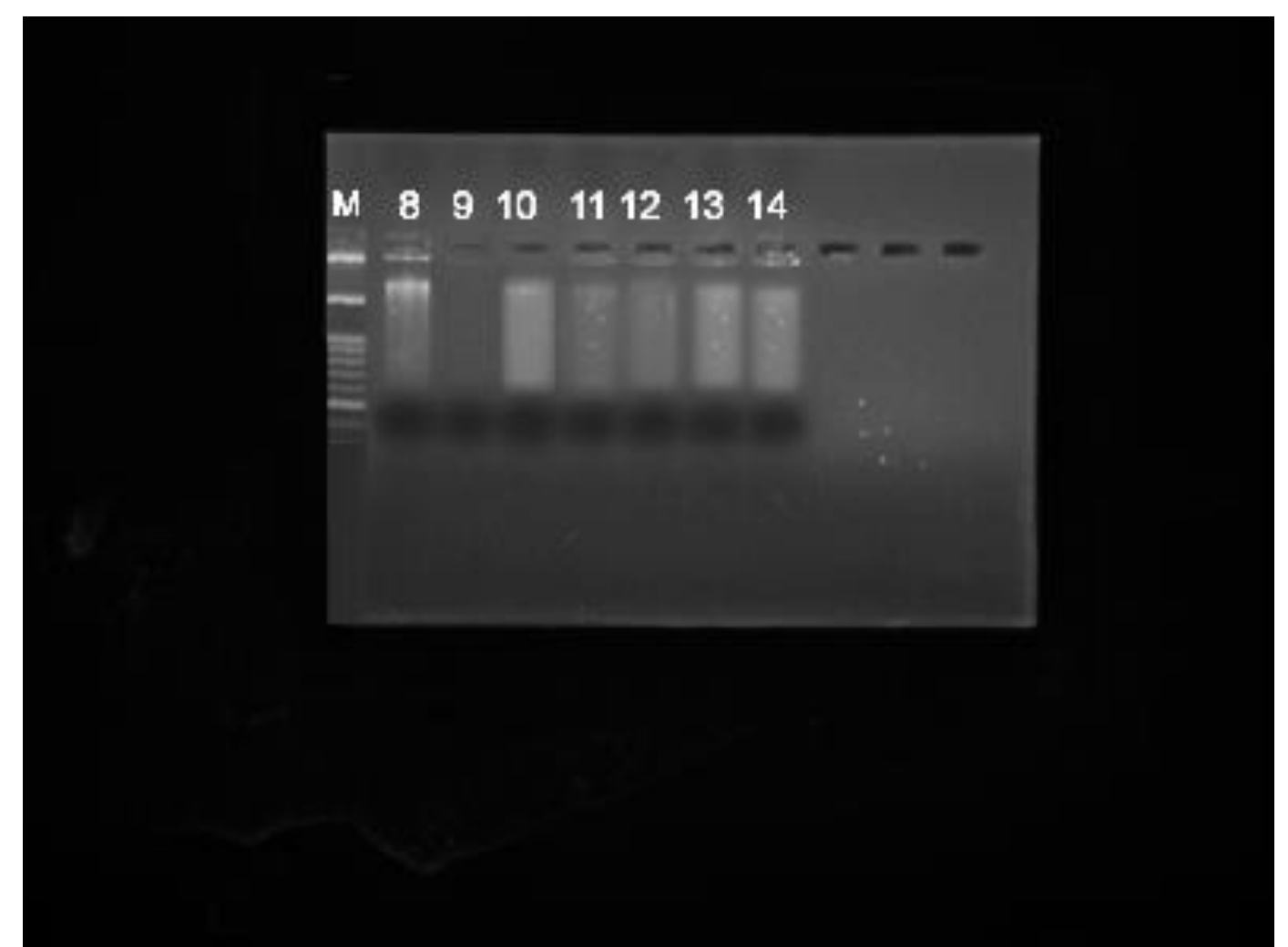

Figure (6): $1 \%$ agarose gel electrophoresis stained with Etidium bromide showing PCR product of amplification of silk cloth samples of all groups $(\underline{M}=3000 \mathrm{bp}$ molecular weight ladder). 


\section{DISCUSSION}

Bloodstain identification is of immense value in crime scene reconstruction, discovering of guilty, and innocence release (Soares-vieira et al., 2001). In human, blood is the most important material available for the isolation of DNA (Lounsbury et al., 2012).

Criminals take precautions to leave minimal trace evidence, or even destroy it completely (Elder et al., 2017). Intended attempt to remove any biological material, using different cleaning products, is a routinely faced problem by forensic scientists. The ability of extraction and PCR amplification of DNA from biological stains is a key element in Forensic Genetics and is frequently inquired by the law enforcement authorities (Dissing et al., 2010). Due to technical improvement, even poor traces, which seemed to be unsuitable for DNA analysis a few years ago, may be amplified successfully today (Harisaranraj et al., 2009 and Kamphausen et al., 2015).

Modern laundry agents include a variety of ingredients aimed to increase laundering effectiveness. These ingredients may be one of the following categories: bleach (oxygen or chlorine), enzymes, surfactants (chemical removal of stains), builders, colorants, fragrances, and specializing components (Bajpai and Tyagi, 2007). These ingredients hydrolyze protein molecules and further cause degradation of bloodstains (Oldfield et al., 2017). Significant damage or alteration to the primary molecular structure of DNA is problematic with subsequent prevention of amplification, and therefore analysis of target loci (Ambers et al., 2014).

The present work was an experimental study designed to evaluate the effect of some cleaning products on the quantity and quality of extracted DNA from bloodstained cloth.

Many Factors can cause failure or inhibition of PCR amplification include extraction technique, technical difficulties, inadequate specimen volume, as well as, the substrates on which the blood is supported (Houston et al., 2016). Dyes, or other watersoluble components may be found in fabrics and act as inhibitory reagents, which require specific methodologies for elimination of these contaminants from forensic samples (Scheithauer and Weisser, 1991). The present experiment was done on white cotton and silk cloth, as they are the most common fibers used in clothes, to facilitate the macroscopic assessment and to avoid any PCR inhibitory components present in cloth (sample or control). They were considered "ideal" by Soares-Vieira et al. (2001), who found fewer difficulties in DNA extraction and absence of amplificationinhibitory reagents.

Documenting the macroscopic image after washing was demonstrated in this study. Considerable amount of blood residues could still be noticed in cotton pieces, while the color was nearly faded in silk pieces of cloth. This was in agreement with Elder et al. (2017) who stated that cotton fabrics had the worst cleaning results; blood residues could still be found on washed textile samples.

Regarding the quantity of extracted DNA in this study, the amounts of recovered DNA from silk cloth was highly significant lower than cotton cloth in all groups including control. This coincide with Mona et al. (2011), who estimated maximum DNA recovery from cotton fabric, followed by silk material. As condition and cleaning substances were same, this quantitative 
differences was due to the fabric chemical structure. Because, $\mathrm{O}-\mathrm{H}$ groups of cotton are capable of formation of strong hydrogen bonds with nucleic acid chains resulting in powerful intermolecular attractions (Seah et al., 2004; Linacre et al., 2010 and Elder et al., 2017).

Regarding cleaning materials used in the current experiment, \{Clorox (bleach), Dettol (disinfectant), Persil (detergent), Vanish (stain remover) and distilled water . Clorox is a common household bleach. It degrades DNA through oxidative damage and the production of chlorinated base products. It is often used to remove blood from crime scenes (Cárdenas Flores et al., 2009 and Passi et al., 2012).

Dettol® $\left(\mathrm{C}_{8} \mathrm{H}_{9} \mathrm{OCl}\right)$; 4-Chloro-3, 5dimethylphenol; para-Chloro-metaxylenol (PCMX) is an antiseptic and disinfectant. It works by disruption of the cell wall and stopping the function of enzymes (Digison, 2007 and Mahon et al., 2014).

Vanish is a popular power stain fighter. Catalase enzyme in blood reported to react with vanish and produce water and oxygen, which attacks and breaks down the bloodstain (McKillop, 1995 and Reckitt Benckiser, 2013).

Persil powder (sodium perborate and sodium silicate) contains stainbusting enzymes, which is effective in breaking down the protein, starches and fats often found in stains (Mahon et al., 2014).

In the presented experiment, the effect of the previous cleaning products on the quantity and quality of extracted DNA from bloodstained cloth was studied. There was highly significant decrease $(p<0.001)$ of amount of extracted DNA in all treated cotton and silk samples as compared to +ve control group.

This was consistent with Houston et al. (2016) who stated that all used laundry additives, in their experiment, significantly reduced the recovery of DNA, though, it is not sufficient to prevent DNA profiling using traditional forensic techniques. Also, Elder et al. (2017) ascertained that DNA could be extracted from all samples of the different textiles had been washed with usual laundry detergents.

Regarding cleaning substances used in this study, Vanish was shown to have the highest cleaning effect, indicated by the decreased amount of extracted DNA from cotton cloth, while Clorox was the least effective one. Many studies had focused on sodium percarbonate (main Vanish ingredient) as a laundry additive hindering the identification of bloodstains (Castelló et al., 2009 and Castelló et al., 2012).

Regarding the quality of the isolated DNA used in PCR amplification reaction, gel electrophoresis of cotton cloth shown in this study, revealed that in Clorox, Persil and Distilled water treated samples, no degradation were observed. Integrated DNA (large and clearly recognizable bands) was indicative of intact DNA. Comparatively, shearing of DNA had been observed with both Vanish and Dettol treated samples, which was indicative of degraded DNA. Gel electrophoresis of silk cloth revealed illdefined shearing of DNA bands in Clorox, Dettol and Distilled water treated samples. Poor yield of DNA had been observed in both Vanish and Persil treated samples.

This was in agreement with Harris et al. (2006) who found appreciably high DNA quality despite the use of chlorinated and non-chlorinated cleaning agents used. They noticed that, 
in bleach treated materials the resultant profiles continued to decline in quality over time, suggesting a continued degradation of the DNA. While, this was not seen in substrates cleaned with soap or non- chlorine disinfectant.

As well as, Ambers et al. (2014) obtained good recovery of DNA from bleach (Clorox) exposed stains. But, they stated that exposure of DNA to increasingly higher concentrations of $\mathrm{NaOCl}$ will eventually cause cleavage of the strands, breaking the DNA into smaller pieces and eventually to individual bases.

Also, Passi et al., 2012 observed that bleaching agent adversely affect the recovery of integrated DNA from the treated blood cells, as short and smeared PCR product had been observed in bleaching agent treated samples.

Regarding stain removers, Castelló et al., 2010 observed certain DNA degradation in stains being treated with Neutrix (stain remover containing $\mathrm{Na}$ percarbonate as source of active oxygen). However, it had not hindered their subsequent amplification. In contrary of that Ambers et al., 2014 found minimal reduction (slight decrease) of DNA content with Oxiclean (another type of stain remover).

\section{CONCLUSION}

Elimination of blood traces in textiles is more difficult than generally believed. This work was done to evaluate the effect of some cleaning products on the quantity and quality of extracted DNA from bloodstained cloth. The data strongly suggested that DNA affected by cleaning additives should still be tested for evidentiary value. From the tested products, Vanish had the most pronounced decreased effects on amount and quality of retrieved DNA. Cotton and silk cloth was used in this study.

\section{Recommendations:}

The use of other fabrics, different exposure time, different additives, different temperature, different environmental conditions, comparison with other extraction protocols and DNA genotyping or profile, are goals of next studies.

\section{REFERENCES}

Ambers, A.; Turnbough, M.; Benjamin, R.; King, J. and Budowle, B. (2014): Assessment of the role of DNA repair in damaged forensic samples. Int. J Legal Med., 128(6):913-921.

Bajpai, D. and Tyagi, V.K. (2007): Laundry detergents: an overview. J Oleo Sci., 56(7):327-340.

Cárdenas Flores, A.; Flores Reyes, H.; Gordillo Moscoso, A.; Castanedo Cázares, J.P. and Pozos Guillén Ade, J. (2009): Clinical efficacy of $5 \%$ sodium hypochlorite for removal of stains caused by dental fluorosis. J Clin. Pediatr. Dent., 33 (3): 187-191.

Castelló, A.; Francés, F. and Verdú, F. (2009): Bleach interference in forensic luminol tests on porous surfaces: More about the drying time effect. Talanta, 77(4): 15551557.

Castelló, A.; Francés, F. and Verdú, F. (2010): DNA evidence uncompromised by active oxygen. Scientific World J, 10:387-392.

Castelló, A.; Francés, F. and Verdú, F. (2012): Chemistry in crime investigation: sodium percarbonate effects on bloodstains detection .J Forensic Sci., 57(2):500-502. Available online at: onlinelibrary.wiley.com

Choi, E.H.; Lee, S.K.; Ihm, C. and Sohn, Y.H. (2014): Rapid DNA extraction from dried blood spots on 
filter paper: potential applications in biobanking. Osong Public Health Res. Perspect., 5(6): 351-357.

Creamer, J.I.; Quickenden, T.I.; Crichton, L.B.; Robertson, P. and Ruhaye, R. A. (2005): Attempted cleaning of bloodstains and its effect on the forensic luminol test. Luminescence, 20(6): 411-413.

de Almeida, J.P.; Glesse, N. and Bonorinoc, C. (2011) : Effect of presumptive tests reagents on human blood confirmatory tests and DNA analysis using real time polymerase chain reaction. Forensic Sci Inter., 206(1-3): 58-61.

Digison, M.B. (2007): A review of antiseptic agents for pre-operative skin preparation. . Plast. Surg. Nurs., 27 (4): 185-189.

Dissing, J.; Søndervang, A. and Lund, S. (2010): Exploring the limits for the survival of DNA in blood stains. J Forensic Leg Med., 17(7):392396.

Edler, C.; Gehl, A.; Kohwagner, J.; Walther, M.; Krebs, O.;Augustin, C. and Klein, A. (2017): Blood trace evidence on washed textiles - a systematic approach. Int. J Legal Med., 131(4): 1179-1189.

Harisaranraj, R.; Suresh, K. and Saravanababu, S. (2009): DNA finger printing analysis among eight varieties of Zingiber officinale Rosc. by using RAPD markers. Glob. J of Mol. Sci., 4 (2): 103-107.

Harris, K.A.; Thacker, C.R.; Ballard, D. and Syndercombe Court, D. (2006): The effect of cleaning agents on the DNA analysis of blood stains deposited on different substrates. Intern. Cong. Ser., 1288:589- 591.

Houston, E.L.; Krane, D. and Goldstein, D. (2016): The effects of various laundering factors on the recoverability of DNA. The Ohio State University. Wright State University CORE Scholar Available at:

http://corescholar.libraries.wright.e du/etd_all/1576(Accessed on 18/11/2017).

Introbio (2015). Instruction Manual, $3^{\text {rd }}$ Edition www.intronbio.com (Accessed on 1/10/2017).

Kamphausen, T.; Fandel1, S.B.; Gutmann, J.S.; Bajanowski, T. and Poetsch, M.(2015): Everything clean? Transfer of DNA traces between textiles in the washtub. Int. J Legal Med., 129(4):709-714.

Kumari , N. and Thakur S. K.(2014): Randomly amplified Polymorphic DNA-a brief review. Amer J of Ani and Vet Sci., 9 (1): 6-13.

Linacre, A.; Pekarek, V.; Swaran, Y. and Tobe, S. (2010): Generation of DNA profiles from fabrics without DNA extraction. Forensic Sci. Int. Genet., 4(2):137-141.

Lounsbury, J.A.; Coult, N.; Miranian, D.C.; Cronk, S.M.; Haverstick, D.M.; Kinnon, P. et al. (2012): An enzyme-based DNA preparation method for application to forensic biological samples and degraded stains. Forensic Sci. Inter. Genet., 6(5):607-615.

Mahon, C. R.; Lehman, D.C. and Manuselis, G. Textbook of Diagnostic Microbiology (5 ed.). (2014). Elsevier Health Sciences. p. 67. Available at ISBN 9780323292627.

McKillop, A. (1995): Sodium perborate and sodium percarbonate: Cheap, safe and versatile oxidizing agents for organic synthesis. Tetrahedron. 51 (22): 6145-6166.

Mona, M. A.; Fadia, M. A.; Azza, E. 
and Nahed, M. M. (2011): Storing DNA on fabric. Published on Forensic Magazine. Available at (http://www.forensicmag.com)

http://www.forensicmag.com/articl es/2011/04/storing-dna-fabric (Accessed on 18/12/2017).

Oldfield, C.; Morgan, R. M.; Miles, H. F. and French, J. C. (2017): The efficacy of luminol in detecting bloodstains that have been washed with sodium percarbonate and exposed to environmental conditions. Australian J of Forensic Sci., 1-10. Available at: http://dx.doi.org/10.1080/00450618 .2016 .1264478 . (Accessed on 18/12/2017).

Passi, N.; Garg, R.K.; Yadav, M.;Singh, R.S. and Kharoshah, M.A. (2012): Effect of luminol and bleaching agent on the serological and DNA analysis from bloodstain. Egyp. J. of Forenic Sci., 2(2): 5461.

Peschel, O.; Kunz, S.N.; Rothschild, M.A. and Mützel, E. (2011): Blood stain pattern analysis. Forensic Sci. Med Pathol., 7(3):257-270.

Phillips, k.; McCallum, N. and Welch, L. (2012): A comparison of methods for forensic DNA extraction: Chelex-100 and the QIAGEN DNA Investigator Kit (manual and automated). Forensic Sci. Inter. Genet., 6(2):282-285.

Reckitt Benckiser, (2013): Vanish is a registered trade mark of the Reckitt Benckiser group of companies. Cited in www.vanish.co.uk .
(Accessed on 14/1/2018).

Scheithauer, R. and Weisser, H.J. (1991): Modification of DNA typing of blood stains by textile stain carriers. Beitr Gerichtl Med., 49:281-284.

Seah, L.H.; Othman, M.I.; Jaya, P. and Jeevan, N.H.( 2004): DNA profiling on fabrics: an in-situ method. Inter. Cong. Ser., 1261: 565- 567.

Shams, S.S.; Vahed, Z.S.; Soltanzad, F.; Kafil, V.; Barzegari, A., Atashpaz, S. and Barar, J. (2011): Highly effective DNA extraction method from fresh, frozen, dried and clotted blood samples. BioImpacts, 1(3):183-187.

Soares-Vieira, J.A.; Muñoz, D.R.; Iwamura, E.S.; de Almeida Cardoso, L. and Billerbeck, A.E. (2001): Analysis of DNA in minute volumes of blood from stains and crusts. Am. J Forensic Med. Path., 22(3):308-312.

Spear, T. and Khoshkebari, N. (2001): Analysis of old biological samples: A study on the feasibility of obtaining body fluid identification and DNA typing results. California Criminalistics Institute (CCI), Sacramento. Available at: https://oag.ca.gov/sites/all/files/agw eb/pdfs/cci/reference/oldstains.pdf (Accessed on 6/6/2017).

van Oorshot, R.A.; Ballantyne, K.N. and Mitchell, R.J. (2010): Forensic trace DNA: a review. Invest. Genet., 1(1):14-31. 


\section{تأثير بعض المنظفات على إسترجاع الحمض النووي للام من القماش

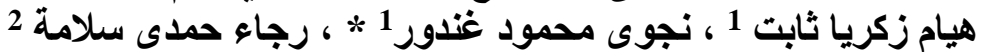

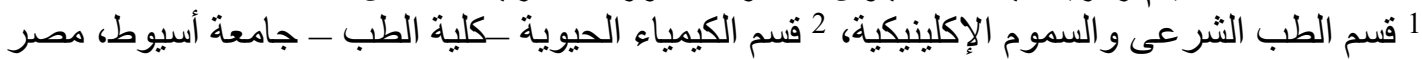

\section{الملخص}

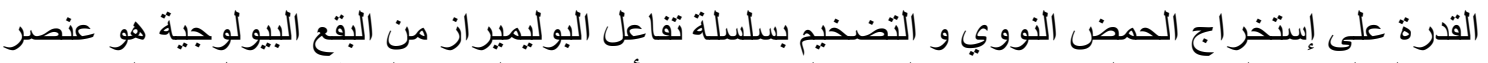

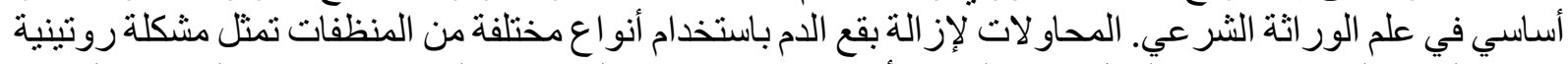

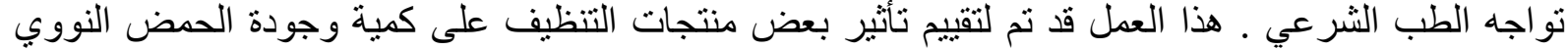
المستخرج من القماش الملطخ بالدماء. الطريقة: عينات الدم تم وضعها على القماش القات القطني و الحريري. بعد التجفيف،

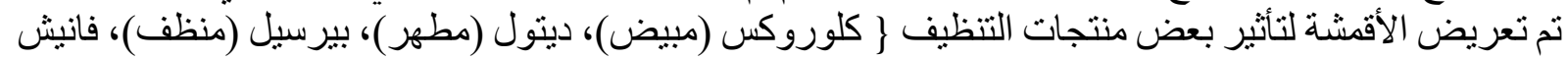

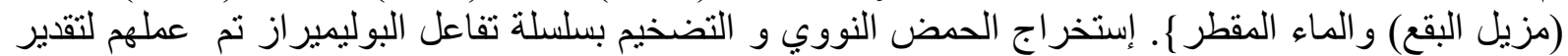

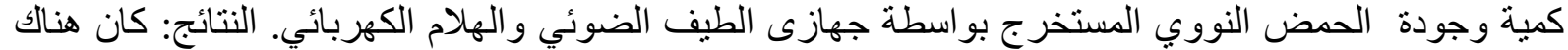

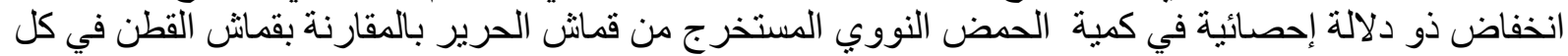

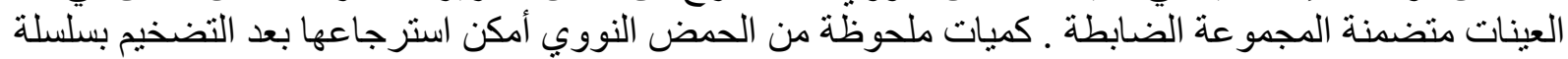

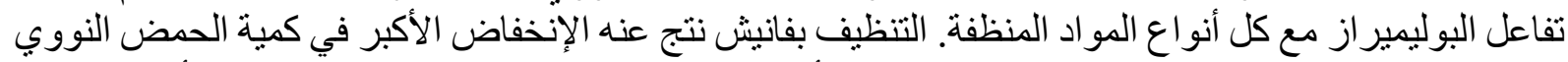

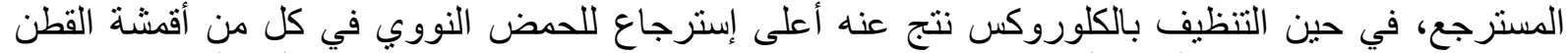

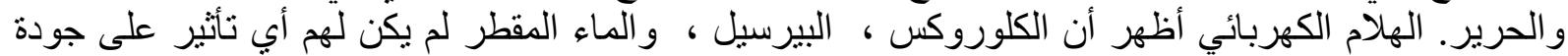

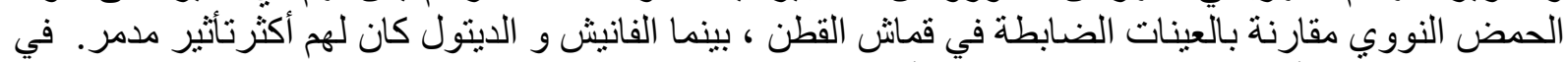

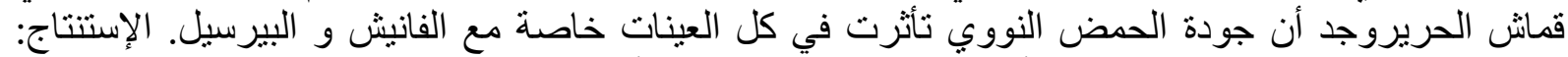

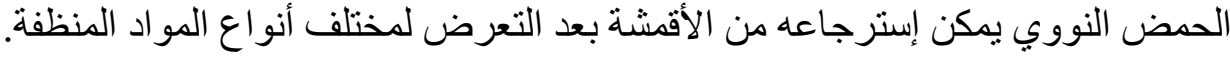

